\title{
PENERAPAN MODEL PEMBELAJARAN BERBASIS MASALAH \\ DALAM MENINGKATKAN KETERAMPILAN BERPIKIR KRITIS \\ POKOK BAHASAN PROBABILITAS MATA KULIAH STATISTIK PADA \\ PERGURUAN TINGGI AMIK DCC BANDAR LAMPUNG
}

\author{
Tsamaniariaty Hidayah \\ AMIK Dian Cipta Cendikia Bandar Lampung \\ tsa.pasca12@yahoo.co.id
}

\begin{abstract}
ABSTRAK
Penelitian ini bertujuan untuk: 1) membuat perencanaan pembelajaran, 2) melakukan pelaksanaan pembelajaran, 3) mengetahui peningkatan keterampilan berpikir kritis mahasiswa, dan 4) mengetahui peningkatan pemahaman mahasiswa melalui model PBM. Penelitian ini merupakan penelitian tindakan kelas dengan mengunakan tiga siklus. Kegiatan setiap siklus yaitu membantu mahasiswa mendefinisikan dan mengorganisasikan tugas belajar, mendorong mahasiswa untuk mengumpulkan informasi, membantu mengembangkan dan menyajikan hasil karya. Penelitian dilakukan pada mahasiswa Perguruan Tinggi AMIK DCC Bandar Lampung Tahun Ajaran 2017/2018, data dikumpulkan dengan observasi dan tes serta dianalisis secara deskriptif analisis. Hasil penelitian adalah: 1) desain pembelajaran sesuai dengan hasil analisis kebutuhan tentang rendahnya kemampuan berpikir kritis dan pemahaman mahasiswa, 2) aktivitas mahasiswa dalam proses pembelajaran adalah dosen membimbing mahasiswa untuk menganalisis dan mengevaluasi proses pemecahan masalah, 3) kemampuan keterampian berpikir kritis mahasiswa mengalami peningkatan setiap siklusnya, dan 4) pemahaman mahasiswa tentang materi juga meningkat setiap siklusnya.
\end{abstract}

Kata kunci: keterampilan berpikir keritis, PBM

\begin{abstract}
This study aims to: 1) make learning planning, 2) carry out learning, 3) know the improvement of students' critical thinking skills, and 4) know the improvement of student understanding through the PBM model. This research is a classroom action research using three cycles. The activities of each cycle are to help students define and organize learning tasks, encourage students to gather information, help develop and present their work. The study was conducted on students of AMIK DCC Bandar Lampung College in Academic Year 2017/2018, data were collected by observation and tests and analyzed by descriptive analysis. The results of the study are: 1) learning design in accordance with the results of the needs analysis about the low critical thinking skills and student understanding, 2) student activities in the learning process are lecturers guiding students to analyze and evaluate problem solving processes, 3) the ability of students to think critically improved every cycle, and 4) students' understanding of matter also increases every cycle.
\end{abstract}

Keywords: critical thinking skills, PBM 


\section{Tsamaniariaty Hidayah}

\section{PENDAHULUAN}

Mengajar merupakan suatu proses penciptaan lingkungan, baik dilakukan oleh guru maupun peserta didik agar terjadi proses belajar mengajar yang kondusif Joyce \& Weil (dalam Tangkas, 2012). Untuk mencapai hasil yang optimal, guru harus memahami berbagai konsep dan teori yang berhubungan dengan proses belajar mengajar. Pengetahuan, keterampilan proses sains, dan sikap ilmiah penting ditanamkan pada peserta didik karena sesuai dengan tujuan Kurikulum 2013, yaitu memberikan pengalaman belajar bermakna dengan cara menggembangkan berbagai sikap, pengetahuan dan keterampilan (Nugraha, Suyitno, \& Susilaningsih, 2017).

Menurut Jean Piaget salah seorang penganut aliran kognitif yang kuat dalam Pargito (2011), bahwa proses belajar sebenarnya terdiri dari tiga tahapan, yakni 1) Asimilasi, 2) Akomodasi, dan 3) Equilibrasi (penyeimbangan). Proses asimilasi adalah proses penyatuan (pengintegrasian) informasi baru ke struktur kognitif yang sudah ada dalam benak mahasiswa. Akomodasi adalah penyesuaian struktur kognitif ke dalam situasi yang baru. Equilibrasi adalah penyesuain berkesinambungan antara asimilasi dan akomodasi.

Maslow mengemukakan bahwa individu berperilaku dalam upaya untuk memenuhi kebutuhan yang bersifat hirarki. Bila seseorang telah dapat memenuhi kebutuhan pertama, seperti kebutuhan psikologis, barulah ia dapat menginginkan kebutuhan yang terletak di atasnya, ialah kebutuhan mendapatkan rasa aman dan seterusnya. Maslow Berfokus pada individu secara keseluruhan, bukan hanya satu aspek individu, dan menekankan kesehatan daripada sekedar penyakit dan masalah.

Menurut Pargito (2011) Pembelajaran Berbasis Masalah (PBM) merupakan terjemahan langsung dari Problem Based Learning (PBL). PBM pada awalnya dirancang oleh Barrow dengan mengikuti ajaran Dewey bahwa dosen harus mengajar sesuai insting alami untuk menyelidiki dan menciptakan sesuatu. Pembelajaran berbasis masalah (PBM) menuntut kreativitas dosen untuk terus melakukan inovasi-inovasi dalam jalannya prosres belajarmengajar di kelas. Pembelajaran berbasis masalah yang merupakan suatu 

Lampung

pembelajaran yang mempunyai perbedaan dengan pembelajaran pada umumnya dilapangan.

Pargito (2011) mengemukakan tujuan pembelajaran berbasis masalah adalah membantu mahasiswa mengembangkan kemampuan berpikir dan memecahkan masalah, mempelajari berbagai peran orang lain melalui keterlibatan mereka dalam pengalaman nyata, menjadi pembelajar yang otonom dan mandiri. Pendekatan pembelajaran berbasis masalah menuntut mahasiswa untuk menyampaikan gagasannya dan berlatih merefleksikan persepsinya, ataupun mengargumentasikan dan mengkomunikasikan pendapatpenadapatnya kepada orang lain. Ibrahim dan Nur (dalam Jumroh, 2008) menyatakan, "Pembelajaran berbasis masalah tidak dirancang untuk membantu dosen memberikan informasi sebanyak- banyaknya kepada mahasiswa".

PBL meurut Nisa (dalam Rerung, Sinon, \& Widyaningsih, 2017) adalah salah satu model pembelajaran inovatif yang memberikan kondisi belajar aktif kepada peserta didik. Menurut Susilo (2012) pembelajaran berdasar masalah dimulai dari masalah yang autentik/sehari-hari dari kehidupan nyata dan bermakna. Dengan demikian dapat dinyatakan bahwa motode pembelajaran berbasis masalah adalah suatu pendekatan pembelajaran yang menggunakan masalah dunian nyata sebagai suatu konteks bagi mahasiswa untuk belajar tentang cara berpikir kritis, keterampilan mengatasi masalah, dan untuk memperoleh pengetahuan dan konsep yang esensial dari materi pelajaran.

Model pembelajaran berbasis masalah menurut Sagala (2009) digunakan untuk merangsang berpikir pada situasi yang berorientasi masalah. Tujuan utama dari metode pembelajaran ini adalah membina sikap dan cara berpikir kritis serta pemberian keterampilan mengatasi masalah. Dalam model pembelajaran ini, mahasiswa tidak hanya belajar dan menerima apa yang disajikan oleh dosen dalam pembelajaran, namun juga dapat belajar dari mahasiswa lainnya serta mempunyai kesempatan untuk membelajarkan mahasiswa yang lain. Melalui model pembelajaran ini, mahasiswa dibiasakan untuk menemukan jalan keluar dari masalah yang dihadapinya sehingga 


\section{Tsamaniariaty Hidayah}

kemampuan mahasiswa untuk belajar mandiri dapat lebih ditingkatkan dan pada gilirannya akan mengoptimalkan prestasi belajar mahasiswa.

Keterampilan dan kemampuan berpikir kritis (critical thinking) akan muncul dalam diri mahasiswa apabila selama proses belajar di dalam kelas, dosen membangun pola interaksi dan komunikasi yang lebih menekankan pada proses pembentukan pengetahuan secara aktif oleh mahasiswa. Sejalan dengan tujuan tersebut, maka skenario pembelajaran berbasis masalah dikemas oleh suatu masalah dan dihadirkan pada permulaan pembelajaran sebelum memperkenalkan konsep yang baru. Pembelajaran berbasis masalah sosial (PBMS) merupakan pembelajaran yang berpusat pada mahasiswa yang menekankan pembelajaran bermakna melalui pemecahan masalah yang bersifat openended. Target akhir pembelajaran adalah terjadinya peristiwa belajar. Belajar sebagai suatu proses aktif, interaktif dan konstruktif terwujud manakala pembelajaran sebagai konteks sosial dan eksternal diterjadikan sebagai mediasi kognitif dan situasi stimulasi. Konteks sosial dimana setiap pebelajar dapat menciptakan makna melalui penginteraksian atau pengaitan diri dengan pengetahuan yang telah ada dalam struktur kognitifnya.

Pembelajaran sebagai suatu sistem tindakan yang dapat mempertemukan antara dimensi-dimensi pembelajaran dengan dimensidimensi belajar. Dalam paradigma ini pula, penggunaan pembelajaran berbasis masalah sosial dalam meningkatkan kemampuan berpikir kritis dan kepekaan sosial mahasiswa pada pembelajaran Statistik menjadi sangat relevan dan argumentatif, menemukan berbagai dimensi pembelajaran, kinerja dosen dan mahasiswa yang dapat meningkatkan iklim sosial pembelajaran Statistik dan memberikan rekomendasi yang diperlukan, baik yang bersifat konseptual tentang pembelajaran Statistik maupun yang bersifat praktis, yaitu mewujudkan perubahan dan peningkatan pada kinerja dosen, kinerja mahasiswa, dan iklim sosial pembelajaran Statistik.

Menurut Pargito (2011) pada dasarnya hidup adalah memecahkan masalah dan hal ini memerlukan kemampuan berpikir kritis dan kreatif. Kritis untuk mengalisis masalah dan kreatif untuk melahirkan alternatif pemecahan masalah. Kedua jenis berpikir tersebut, kritis dan kreatif, berasal dari rasa ingin 

Lampung

tahu dan imajinasi yang keduanya ada pada diri anak sejak lahir. Oleh karena itu, tugas dosen adalah mengembangkannya, antara lain dengan sering-sering memberikan tugas atau mengajukan pertanyaan yang terbuka. Pertanyaan yang dimulai dengan kata-kata "apa, berapa dan kapan”, yang umumnya tertutup (jawaban betul hanya satu).

Tujuan berpikir kritis, Pargito (2011) ialah untuk menguji suatu pendapat atau ide, termasuk dalam proses ini adalah melakukan pertimbangan atau pemikiran didasarkan pada pendapat yang diajukan. Pertimbanganpertimbangan itu biasanya didukung oleh kriteria yang dapat dipertangung jawabkan. Sedangkan tujuan kemampuan berpikir kritis adalah kemampuan memberikan alasan, berpikir secara reflektif dan fokus untuk menentukan apa yang akan dilakukan atau apa yang diyakini.

Desain pembelajaran keterampilan berpikir (thinking skills) ada dua fokus model desain pembelajaran untuk keterampilan berpikir, yaitu keterampilan berpikir kritis (critical thinking skill), dan keterampilan berpikir kreatif (creative thinking skill). Pada hakekatnya, model desain pembelajaran merupakan alternatif model yang dapat dipilih oleh dosen untuk ditetapkan dalam proses belajar mengajar Statistik. Prinsip Model desain pelajaran berpikir kritis dan kreatif memiliki beberapa kesamaan dengan inkuiri, yaitu sama-sama untuk membantu anak berlatih berpikir kritis dan memecahkan berbagai masalah kehidupan pribadi mahasiswa maupun kemasyarakatan. Oleh karena itu, pemahaman terhadap model desain pembelajaran inkuiri akan sangat membantu dalam memahami desain pembelajaran berpikir.

Keterampilan berpikir kritis yang menggunakan dasar proses berpikir sangat membantu mahasiswa dalam memecahkan kesulitan yang diketahui atau didefinisikan, mengumpulkan fakta tentang kesulitan tersebut dan menentukan informasi tambahan yang diperlukan. Pengambilan keputusan menggunakan dasar proses berpikir untuk memilih respon terbaik diantara beberapa pilihan mengumpulkan informasi yang dibutuhkan dalam lingkup topik, membandingkan keuntungan dan kerugian dari alternatif-alternatif pendekatan, dan menentukan informasi tambahan yang dibutuhkan. 


\section{Tsamaniariaty Hidayah}

Pembahasan ini akan lebih difokuskan pada uraian keterampilan berpikir kritis mengingat kemampuan berpikir ini sangat dianjurkan oleh para ahli pendidikan ilmu sosial. Namun, kemampuan berpikir kreatif juga akan disinggung, terutama keterkaitannya dengan keterampilan berpikir kritis. Berpikir kritis merupakan istilah yang digunakan untuk suatu aktivitas reflektif untuk mencapai tujuan yang memuat keyakinan dan perilaku yang rasional. Ia pun telah melakukan identifikasi lima kunci unsur berpikir kritis, yakni "praktis, reflektif, rasional, terpercaya, dan berupa tindakan".

\section{METODE PENELITIAN}

Metode dalam penelitian ini adalah metode penelitian tindakan kelas (classroom action research). Penelitian tindakan kelas merupakan suatu kajian kritis reflektif dan sistematis terhadap pembelajaran melalui tindakan yang dilakukan secara berulang-ulang (siklus) sampai ditemukan tindakan yang tepat (ideal) dalam rangka mencapai tujuan. Lebih sederhananya penelitian tindakan kelas adalah kajian perbaikan pembelajaran melalui tindakan tertentu yang dilakukan secara berulang-ulang hingga menemukan tindakan yang tepat dalam mencapai tujuan yang diharapkan (Pargito, 2011). Metode penelitian tindakan kelas ini digunakan untuk mengetahui langkah pembelajaran yang tepat untuk meningkatkan kemampuan berpikir kritis melalui model pembelajaran berbasis masalah sosial, dengan selalu memperbaiki langkah pembelajaran pada setiap siklusnya berdasarkan rekomendasi dari siklus sebelumya.

Penelitian tindakan kelas yang dilaksanakan mengacu pendapat Darmadi (2011), yakni dilakukan tes awal (pretest) terhadap kedua kelas tersebut berupa soal tes. Setelah dilakukan tes awal kemudian kedua kelas mendapat pembelajaran berbasis masalah sosial, dan diakhiri dengan pemberian tes akhir (posttest). Perangkat soal tes awal dan tes akhir menggunakan perangkat tes yang sama.

Rancangan penelitian pada umumnya dilakukan secara siklikal atau siklus, tiap siklus atau putaran terdiri dari kegiatan perencanaan (planning), tindakan (acting), observasi (observing), dan refleksi (reflecting). 

Lampung

\section{HASIL PENELITIAN DAN PEMBAHASAN}

Berdasarkan hasil penelitian yang telah dilakukan, terdapat beberapa hasil dalam pelaksanaan penelitian pada siklus 1 sampai siklus 3 sebagai berikut:

1. Rencana pelaksanaan pembelajaran (RPP) berbasis masalah dalam mengembangkan kemampuan berpikir dan memecahkan masalah mahasiswa, mempelajari berbagai peran orang lain melalui keterlibatan mereka dalam pengalaman nyata, menjadi pembelajar yang otonom dan mandiri. Tahapan-tahapan dalam pelaksanaan pembelajaran berbasis masalah adalah:

a. Tahap 1, orientasi mahasiswa pada masalah

Pada tahap memberikan orientasi mahasiswa kedalam masalah serta memberikan masalah kepada mahasiswa tentang materi yang sedang dipelajari.

b. Tahap 2, mengorganisasikan mahasiswa untuk belajar

Pada tahap mengorganisasikan mahasiswa untuk belajar dosen memberikan bimbingan dan arahan kepada mahasiswa untuk mengorganisasikan masalah.

c. Tahap 3, membimbing penyelidikan idividu atau kelompok Pada tahap membimbing penyelidikan individu dan kelompok.

d. Tahap 4, mengembangkan dan menyajikan hasil karya Pada tahap mengembangkan dan menyajikan hasil karya dosen merancang mahasiswa untuk dapat mengelompokkan masalah.

e. Tahap 5, menganalisis dan mengevaluasi proses pemecahan masalah Pada tahap menganalisis dan mengevaluasi proses pemecahan masalah dosen membantu mahasiswa untuk melakukan evaluasi terhadap tugas dan proses yang mahasiswa gunakan.

2. Pelaksanaan pembelajaran berbasis masalah merupakan pengembangan dari rencana pelaksanaan pembelajaran berbasis masalah. Melalui langkahlangkah pelaksanaan pembelajaran berbasis masalah mahasiswa diarahkan untuk menyelesaikan masalah secara ilmiah dengan mengembangkan 


\section{Tsamaniariaty Hidayah}

kemampuan berpikir kritis mahasiswa. Tahap-tahap pelaksanaan pembelajaran berbasis masalah dalam pembelajaran ini sebagai berikut:

a. Tahap 1, memberikan orientasi mahasiswa pada masalah

Dalam pelaksanaan pembelajaran di tahap memberikan orientasi mahasiswa ke dalam masalah adalah mahasiswa berkumpul dengan kelompoknya dengan cara melingkar sehingga semua anggota kelompok dapat bekerjasama dengan baik. Kemudian mahasiswa diberikan masalah tentang materi yang sedang dipelajari. Mahasiswa menyiapkan semua buku yang berhubungan dengan materi yang sedang dibicarakan.

b. Tahap 2, mengorganisasikan mahasiswa untuk belajar

Pada tahap mengorganisasikan mahasiswa untuk belajar, mahasiswa diberikan bimbingan dan arahan untuk mengorganisasikan masalah yang dosen berikan. Kemudian mahasiswa mendefinisikan masalah yang diberikan.

c. Tahap 3, membimbing penyelidikan idividu atau kelompok

Pada tahap membimbing penyelidikan individu dan kelompok mahasiswa mengumpulkan informasi yang dapat membantu dalam menemukan masalah.

d. Tahap 4, mengembangkan dan menyajikan hasil karya

Pada tahap mengembangkan dan menyajikan hasil karya mahasiswa untuk mengelompokkan masalah dan jawaban yang telah didapatkan.

e. Tahap 5, menganalisis dan mengevaluasi proses pemecahan masalah Pada tahap menganalisis dan mengevaluasi proses pemecahan masalah mahasiswa untuk melakukan evaluasi terhadap tugas dan proses.

3. Peningkatan kemampuan berfikir kritis yang dilakukan dalam penelitian ini meliputi unsur-unsur praktis, reflektif, rasional, terpercaya dan tindakan. Keempat unsur tersebut yang peneliti nilai dalam penelitian ini dan pada akhir siklus 3 semua kemampuan tersebut dapat berhasil dengan amat baik. Peningkatan keterampilan berpikir kritis mahasiswa menggunakan PBM meningkatkan pada setiap siklusnya. Meskipun penelitian ini belum menjadikan seluruh mahasiswa di kelas tersebut mencapai kriteria 
keterampilan berpikir keritis, namun penelitian ini telah mencapai indikator yang ditetapkan, sehingga penelitian ini dinilai sangat baik digunakan untuk meningkatkan kemampuan berpikir kritis mahasiswa.

Pemahaman materi melalui model pembelajaran berbasis masalah sangat baik. Terihat peningkatannya pada setiap siklusnya semakin membaik. Sehingga peneliti memutuskan bahwa dengan menggnakan pembelajaran berbasis masalah selain dapat meningkatkan keterampilan berpikir kritis mahasiswa tetapi juga dapat meningkatkan pemahaman mahasiswa.

\section{1) Perencanaan Pembelajaran}

Perencanaan pembelajaran dalam penelitian ini menjadi acuan bagi peneliti untuk melaksanakan penelitian sesuai runtutan rencana yang telah dibuat menggunakan desain pembelajaran ASSURE. Pada perencanaan pembelajaran terdapat kegiatan inti yang tercantum pada proses pembelajaran dengan menerapkan metode pembelajaran PBM. Peneliti menganalisis terlebih dahulu mahasiswa, mulai dari karakteristik mahasiswa dan bagaimana gaya belajar mereka, setelah itu menentukan standar dan tujuan pembelajaran yang digunakan peneliti untuk memilih strategi, media dan bahan ajar yang ingin digunakan hingga melakukan evaluasi dan revisi, itu semua peneliti lakukan untuk mengetahui pembelajaran yang pas digunakan. Setelah seluruhnya dianalisis peneliti memutuskan untuk menggunakan model PBM dalam meningkatkan kemampuan berpikir kritis dan pemahaman Statistik mahasiswa.

Pembelajaran berbasis masalah pada awalnya dirancang oleh Barrow dengan mengikuti ajaran Dewey bahwa dosen harus mengajar sesuai insting alami untuk menyelidiki dan menciptakan sesuatu. Pembelajaran berbasis masalah menuntut kreativitas dosen untuk terus melakukan inovasi-inovasi dalam jalannya prosres belajar-mengajar di kelas. Pembelajaran berbasis masalah yang merupakan tafsiran dari Problem based learning, merupakan suatu pembelajaran yang mempunyai perbedaan dengan pembelajaran pada umumnya di lapangan. 


\section{Tsamaniariaty Hidayah}

\section{2) Pelaksanaan Pembelajaran}

Di dalam pelaksanaan pembelajaran berbasis masalah, peserta didik sebagai pusat pembelajaran atau student-centered, sementara dosen berperan sebagai fasilitator yang memfasilitasi mahasiswa untuk secara aktif menyelesaikan masalah dan membangun pengetahuannya secara berpasangan ataupun berkelompok (kolaborasi antar mahasiswa). Pembelajaran membahas dan memecahkan masalah autentik adalah kegiatan yang mahasiswa lakukan dalam proses pembelajaran, selain itu mahasiswa didorong untuk dapat menyusun pengetahuan sendiri, menumbuhkan keterampilan yang lebih tinggi, melatih kemandirian mahasiswa, dan dapat meningkatkan kepercayaan diri mahasiswa. Masalah autentik diartikan sebagai masalah kehidupan nyata yang ditemukan mahasiswa dalam kehidupan sehari-hari. Hal tersebutlah yang peneliti lakukan dalam perannya sebagai dosen didalam pelaksanaan pembelajaran.

\section{3) Kemampuan Berpikir Kritis}

Keterkaitan antara pengaruh strategi pembelajaran berbasis masalah terhadap kemampuan berpikir kritis dan pemahaman konsep dapat dijelaskan hawa strategi pembelajaran berbasis masalah yang diterapkan memberikan peluang kepada mahasiswa untuk mengembangkan kemampuan berpikirnya. Strategi ini menekankan pada kemampuan memecahkan masalah yang kompleks sehingga secara tidak langsung melatih mahasiswa untuk mengembangkan kemampuan berpikirnya. Apabila seorang mahasiswa telah dapat mengembangkan kemampuan berpikir kritis maka mahasiswa tersebut dapat menginterpretasi informasi yang diperoleh untuk ditarik kesimpulan menjadi suatu konsep yang dapat dipertanggungjawabkan. Dengan demikian, kemampuan berpikir mahasiswa yang meningkat akan mempermudah mahasiswa dalam menyerap konsep-konsep yang dipelajari.

\section{4) Pemahaman Mahasiswa}

Pemahaman merupakan salah satu bentuk hasil belajar yang telah dilakukan oleh mahasiswa. Pemahaman mahasiswa ini terbentuk akibat dari adanya proses belajar yang diberikan oleh dosen. Pemahaman berarti mengerti benar atau mengetahui benar bahan pelajaran yang diberikan oleh dosen. Pemahaman dapat juga diartikan menguasai sesuatu dengan pikiran. Karena itu, 

Lampung

maka belajar berarti harus mengerti secara mental makna dan filosofinya, maksud dan implikasi serta aplikasi-aplikasinya, sehingga menyebabkan mahasiswa memahami suatu situasi. Hal ini sangat penting bagi mahasiswa yang belajar. Memahami maksudnya, menangkap maknanya, adalah tujuan akhir setiap mengajar. Pemahaman memiliki arti sangat mendasar yang meletakkan bagianbagian belajar pada porsinya. Tanpa itu, maka pengetahuan, keterampilan, dan sikap tidak akan bermakna.

\section{SIMPULAN}

Berdasarkan hasil penelitian tindakan kelas yang telah dilaksanakan, dapat disimpulkan bahwa:

1. Perencanaan pelaksanaan pembelajaran pada setiap siklus dalam penelitian ini merupakan tahapan-tahapan dalam pembelajaran berbasis masalah. Tahapan dalam perencanaan pembelajaran ini selalu diperbaiki setiap siklusnya. Hal tersebut dikarenakan untuk mendapatkan hasil yang baik.

2. Pelaksanaan pembelajaran berbasis masalah merupakan pengembangan dari rencana pelaksanaan pembelajaran. Tahapan dalam kegiatan dilakukan dosen untuk mengembangkan kemampuan berpikir kritis mahasiswa.

3. Peningkatan kemampuan berfikir kritis yang dilakukan dalam penelitian ini meliputi unsur-unsur praktis, reflektif, rasional, terpercaya dan tindakan. Kelima unsur tersebut yang peneliti nilai dalam penelitian ini dan pada akhir siklus 3 semua kemampuan tersebut dapat berhasil dengan amat baik.

4. Pemahaman materi melalui model pembelajaran berbasis masalah sangat baik. Terihat peningkatannya pada setiap siklusnya semakin membaik. Sehingga peneliti memutuskan bahwa dengan menggunakan pembelajaran berbasis masalah selain dapat meningkatkan keterampilan berpikir kritis mahasiswa tetapi juga dapat meningkatkan pemahaman mahasiswa.

\section{DAFTAR PUSTAKA}

Darmadi. (2011). Belajar dan Pembelajaran. Jakarta: Rineka Cipta. Jumroh. (2008). Kondisi Belajar dan Teori Pembelajaran. Jakarta. 
Nugraha, A. J., Suyitno, H., \& Susilaningsih, E. (2017). Analisis Kemampuan Berpikir Kritis Ditinjau dari Keterampilan Proses Sains dan Motivasi Belajar melalui Model PBL. Journal of Primary Education, 6(1), 35-43.

Pargito. (2011). Penelitian Tindakan Kelas bagi Dosen dan Dosen. Bandar Lampung: Anugrah Utama Raharja (AURA).

Rerung, N., Sinon, I. L. S., \& Widyaningsih, S. W. (2017). Penerapan Model Pembelajaran Problem Based Learning (PBL) untuk Meningkatkan Hasil Belajar Peserta Didik SMA pada Materi Usaha dan Energi. Jurnal Ilmiah Pendidikan Fisika Al-Biruni, 6(1), 47-55.

Sagala. (2009). Pemanfaatan Buku Teks dalam Proses Belajar Mengajar. Bandung: CV. Remaja Karya.

Susilo, A. B. (2012). Pengembangan Model Pembelajaran IPA Berbasis Masalah untuk Meningkatkan Motivasi Belajar dan Berpikir Kritis Siswa SMP. Journal of Primary Educational, 1(1), 57-63.

Tangkas, I. M. (2012). Pengaruh Implementasi Model Pembelajaran Inkuiri Terbimbing Terhadap Kemampuan Pemahaman Konsep dan Keterampilan Proses Sains Siswa Kelas X SMAN 3 Amlapura. Jurnal Pendidikan dan Pembelajaran IPA Indonesia, 2(1), 1-17. 